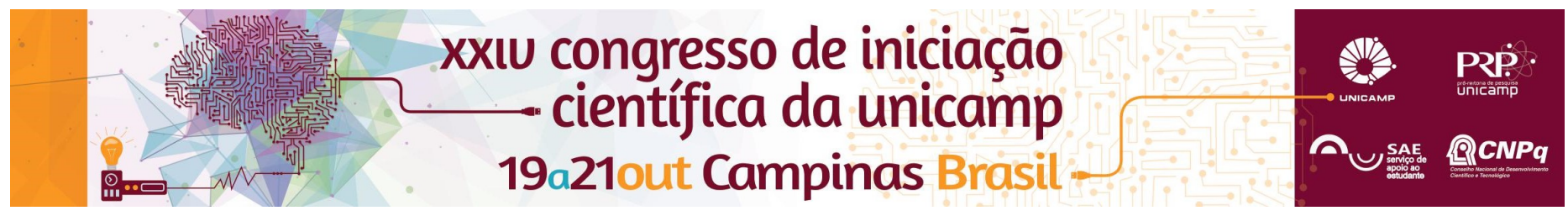

\title{
O ensino-aprendizagem de língua estrangeira e o papel transformador da tecnologia: a web 2.0 como ferramenta transcultural
}

\section{Aline S. Vinci}

\section{Resumo}

O foco da pesquisa em questão é o ensino-aprendizagem de língua estrangeira (LE) em contexto universitário e sua relação com as tecnologias digitais. Seu objetivo principal é investigar estratégias de ensino que se mostrem mais sensíveis às questões sociais e culturais, favorecendo a aprendizagem no que se refere à construção de multiletramentos, sob uma perspectiva ética e cidadã, na sociedade atual.

\section{Palavras-chave: \\ Língua estrangeira; Ensino-aprendizagem; Tecnologia}

\section{Introdução}

O cenário que dá bases para esta investigação é o ProFIS (Programa de Formação Interdisciplinar Superior) na Universidade Estadual de Campinas (UNICAMP). De modo mais específico, o contexto gerador de dados serão as aulas práticas da disciplina de Língua Inglesa III ( $1^{\circ}$ semestre de 2016), envolvendo seu processo de planejamento, desenvolvimento e avaliação de resultados, mais especificamente, ao desenvolvimento do que se intitula Projeto Colaborativo. Essas aulas são reservadas às atividades práticas das disciplinas, e são ministradas nos laboratórios de informática.

No âmbito teórico, esta pesquisa converge com a perspectiva Vygotskyana (Vygotsky, 1984, 1987) de que o desenvolvimento cognitivo do aluno se dá por meio da interação social, ou seja, de seu contato com outros indivíduos e com o meio. A construção de conhecimento é assim, socioculturalmente mediada. Em vista disso, é preciso que o aluno construa seu conhecimento em grupo com participação ativa e a cooperação de todos os envolvidos. A orientação do professor deve possibilitar a criação de ambientes de participação, colaboração e constantes desafios.

Nesse contexto, a educação linguística é um instrumento de participação social que fortalece a relação com a pluralidade linguística e cultural, por meio da construção de letramentos (COPE e KALANTZIS, 2000; ROCHA, 2012). Na sociedade globalizada em que vivemos, o desenvolvimento de uma postura crítica, que favoreça uma relação mais aberta com a diversidade cultural (ROJO, 2014, 2015) são de suma importância.

Essas teorizações mostram-se adequadas para sustentar atividades colaborativas, de bases críticas e transculturais, que podem ser potencializadas com a presença das tecnologias, em especial da Web 2.0 nas salas de aula de língua estrangeira no contexto estudado. Portanto, esta pesquisa pretende compreender como a tecnologia se faz presente no espaço das aulas práticas das disciplinas de Língua Inglesa do ProFIS, avaliando se e em que medida essas tecnologias e as propostas a ela relacionadas favorecem um processo de ensinoaprendizagem de cunho crítico e transcultural no contexto em que estão inseridas.

\section{Desenvolvimento}

O primeiro semestre da pesquisa seria dedicado a três principais atividades: levantamento bibliográfico, pesquisa de ferramentas da Web 2.0 e observação de aulas. Entretanto, não foi possível efetuar a observação das aulas no primeiro semestre do estudo devido ao processo de validação do Comitê de Ética em Pesquisa (CEP/UNICAMP), ao qual esta pesquisa foi submetida por envolver seres humanos no que se refere à geração de dados. Os meses de agosto e setembro foram destinados à elaboração do projeto e obtenção da documentação a partir das diretrizes exigidas pelo CEP, sendo o projeto final submetido em outubro. A aprovação foi comunicada no mês de dezembro de 2015.

No entanto, a bolsa Pibic/CNPq foi cancelada no mês de março devido ao início de vínculo empregatício, impedindo que fosse dada continuidade às atividades propostas.

\section{Resultados}

Como resultado da integração com o grupo de pesquisa E-lang $(\mathrm{CNPq})$, liderado pelas pesquisadoras Cláudia Hilsdorf Rocha e Denise Bértoli Braga, e como também do levantamento teórico, foi desenvolvido um artigo intitulado "O ensino de Língua Estrangeira a partir de uma perspectiva intercultural", com autoria de Aline Silva Vinci e Verônica Zandona Prado que tem por objetivo conjugar duas pesquisas em nível de graduação em desenvolvimento quanto a seus aportes teóricos e questões de estudo em comum em relação à presença $e$ abordagem do conceito de cultura no ensino de língua estrangeira (LE) bem como sua inclusão em uma forma outra de se pensar a educação linguística a partir de uma perspectiva trans ou intercultural. Este foi publicado no Dossiê Especial:Formação Docente, Tecnologias Digitais e Educação Crítica. ROCHA; HIBARINO e AZZARI (orgs.) Revista X, vol.2, 2015 e está disponível em: http://revistas.ufpr.br/revistax/article/view/43778

COPE, B.; KALANTZIS, M. (Eds.). Multiliteracies: Literacy Learning and the Design of Social Futures. London: Routledge, 2000

ROJO, R. H. R. . Gêneros de Texto/Discurso e os desafios da contemporaneidade. 1. ed. Campinas: Pontes Editores, 2014.

ROJO, R. H. R.; BARBOSA, J. P. . Hipermodernidade, multiletramentos e gêneros discursivos. 1. ed. São Paulo: Parábola Editorial, 2015

VYGOTSKY, L.S. Formação social da mente. São Paulo: Martins Fontes, 1984.

Fontes, 1987. 